\title{
CHRZEŚCIJAŃSKI NEOPLATONIZM - SYNTEZA DUCHOWYCH TRADYCJI WSCHODU I ZACHODU
}

Począwszy od Tertuliana aż do czasów obecnych wielu myślicieli próbowało wymierzyć symboliczną odległość między Atenami a Jerozolimąa ${ }^{1}$. W szkicu tym nie zamierzam udawać bezstronnego mierniczego; przeciwnie - chciałbym ukazać te symboliczne metropolie jako miasta bliźniacze, od wieków złączone wspólną historią. Dlatego też pozostawiając innym szukanie różnic, niezgodności i waśni, chciałbym się przyjrzeć splataniu się wątków religijnych i filozoficznych u wczesnych autorów chrześcijańskich, za głównych bohaterów mojej refleksji biorąc dwóch autorów należących wprawdzie do greckiego nurtu patrystyki, ale pochodzących z obszarów wschodniej części Cesarstwa Rzymskiego zamieszkałych w większości (i prawdopodobnie z tej większości się wywodzących) przez ludność niegreckiego pochodzenia: Egipcjan i Syryjczyków. Symbolicznie wybieram też ich z uwagi na czas, w jakim tworzyli: Egipcjanin Orygenes należy do pierwszego pokolenia twórców chrześcijańskiej teologii, anonimowy Syryjczyk znany pod imieniem Pseudo-Dionizego Areopagity zaś pisze swe dzieła pod koniec okresu patrystycznego już po ukształtowaniu dogmatycznych podstaw doktryny chrześcijańskiej przez sobory w Nicei (325 r.) i Chalcedonie (451 r.).

Nie ulega wątpliwości, że od samego swego początku (jak zaświadcza Prolog do Ewangelii św. Jana swoim odwołaniem do Logosu) (por. Jan 1:1-3) chrześcijaństwo poszukiwało w filozofii odpowiedniego narzędzia do przedstawiania swej doktryny. Co więcej, wielu badaczy zgadza się, że to decyzja o przedstawieniu nauczania Jezusa i jego uczniów w języku filozofii sprawiła, że chrześcijaństwo stało się globalną religia, a nie pozostało jedynie niewielkim, heretyckim odłamem judaizmu. Oferta szkół

1 "What has Jerusalem to do with Athens, the Church with the Academy, the Christian with the heretic?". Tertullian, „Prescription against Heretics”, por. (Roberts, Donaldson 1994, s. 249). 
filozoficznych była szeroka, ale chrześcijańscy autorzy w niedługim czasie opowiedzieli się za jedną z nich: platonizmem². To w tej filozofii chrześcijanie bardzo szybko potrafili odnaleźć język, który z jednej strony pozwolił im samym wyrazić treści zawarte w swojej wierze, a z drugiej umożliwił im komunikowanie tych treści także tym, którzy się jeszcze z nią nie spotkali. Doskonale ilustruje to historia Justyna Męczennika, apologety z II w., który, jak sam pisze, poszukiwał prawdy w różnych szkołach, zanim spotkał Jezusa - Prawdę wcielona, a przedostatnim, wskazującym kres, przystankiem jego intelektualnej podróży była doktryna Platona (Altaner, Stuiber 1990, s. 129). To myśl Platona odkryła przed nim wieczny, niezmienny i doskonały świat transcendencji, kierując go na drogę do $\mathrm{Ab}$ solutu, w którym ostatecznie zobaczył chrześcijańskiego Boga. Droga z Aten do Jerozolimy była więc dla Justyna, Greka osiadłego w Palestynie, prosta i niezbyt długa.

O ile dla Justyna filozofia wyznaczała kierunek ku wierze, o tyle chrześcijańscy myśliciele następnych pokoleń starali się już splatać obydwa wątki. Szczególne znaczenie miała szkoła katechetyczna w Aleksandrii (II-III w.), która położyła fundamenty pod chrześcijańską teologię. Założona została przez Klemensa Aleksandryjskiego, który chlubił się tym, że jego nauczyciele wiary byli uczniami apostołów (Klemens z Aleksandrii 1994, s. 8-9). Jednocześnie stała się pierwszym ośrodkiem chrześcijańskiej recepcji Platona, choć sam Klemens, tworząc doktrynę nazywaną przez niego samego gnozą chrześcijańska, korzysta z dorobku niemal całej kultury helleńskiej. Prawdziwym „swatem” mariażu chrześcijaństwa i platonizmu jest uczeń Klemensa, Orygenes. Kształcił się on w tej samej filozoficznej atmosferze co Plotyn, pogański odnowiciel platonizmu, i prawdopodobnie jego kolega z wykładów Ammoniusza Sakkasa, aleksandryjskiego Sokratesa, który wielu młodych ludzi skierował ku tej filozofii (Plotyn 2000, s. 64). Jego chrześcijaństwo na tyle nasiąkło myślą platońska, że dla wielu swych współwyznawców stał się odszczepieńcem, a niektóre jego poglądy zostały potępione, co nie przeszkadzało zbytnio chrześcijańskim autorom nadal z nich korzystać. W ten sposób, chociaż sam Orygenes nie jest zaliczany do ojców Kościoła, jest on swego rodzaju patronem całej tej grupy, bo dzięki parafrazie $O$ zasadach, swego głównego dzieła, dokonanej przez Rufina, stał się znany również wśród łacinników (por. Pietras 1996, s. 6-7).

${ }^{2}$ Miały także miejsce próby budowania nauki chrześcijańskiej na podstawie innych założeń filozoficznych. Najbardziej znana jest autorstwa wspomnianego wyżej Tertuliana, odwołująca się do stoickiego materializmu, ale były izolowane i krótkotrwałe, por. (Gilson 1987, s. 516). 
Przyjmując neoplatonizm jako swój ,"język ojczysty”, wczesne chrześcijaństwo szybko stało się neoplatońskie do szpiku kości, tzn. w swoim nauczaniu umiało ujmować i badać wszystkie i tylko te treści, które dało się w tym języku wyrazić. Konsekwencją takiego podejścia było pomijanie wszystkiego tego, co choć obecne w przekazie biblijnym, niezgodne było z filozoficznymi zasadami platonizmu. Wzorując się na Filonie z Aleksandrii, wcześniejszym o dwa stulecia żydowskim filozofie próbującym $\mathrm{w}$ terminach platońskich interpretować Biblię, Orygenes przeprowadza egzegezę tekstów objawionych, wyróżniając w nich sens literalny (często ujęty historycznie), moralny i mistyczny. Ten trojaki podział wyprowadza z pochodzącej od św. Pawła trychotomicznej koncepcji człowieka jako składającego się z ciała, duszy i ducha (Ga 5:25-26). Najważniejszy dla niego jest, rzecz jasna, odnoszący się do ducha sens mistyczny, którego celem jest doskonalenie jednostkowej duszy, by przygotować ją na zjednoczenie z Bogiem. W wydobywaniu tego sensu pomocna jest, zdaniem Orygenesa, mądrość filozofów pogańskich, jako że w każdym człowieku znajdują odblaski światła boskiego Logosu, a ewangelia jedynie wypełniła (zaktualizowała) to, co potencjalnie znajdowało się już u filozofów. $Z$ tego powodu chrześcijański nauczyciel bez wahania powinien przejmować od pogan wszystko, co w helleńskiej kulturze jest dobre i zdrowe. W Przeciw Celsusowi pisze, że ludzka mądrość jest sposobem kształcenia duszy, którego kresem jest mądrość boska (por. Orygenes 2001, III, s. 58; VI, s. 13-14). Filozofia nie jest wprawdzie nieodzowna do zdobycia prawdy boskiego objawienia, bo prostaczkom wystarczy dosłowny i moralny sens Pisma, by osiągnąć mądrość przewyższającą dokonania pogan, ale jest niezwykle pomocna w obronie chrześcijaństwa. Logika broni wiary nie mniej skutecznie niż cuda i spełnione proroctwa. Naturalnie, filozofia i słowo Boże nie zawsze są w zgodzie, ale też nie sprzeciwiają się sobie tak, by pojednanie nie było możliwe.

Najbardziej wyraźnie zastosowanie tej strategii interpretacyjnej widać w Orygenesowej koncepcji człowieka. Czysto platońskie ujęcie, widzące $\mathrm{w}$ ciele więzienie, $\mathrm{w}$ którym dusza odbywa pokutę za grzechy popełnione w poprzednim życiu, nie mogło zostać przyjęte z uwagi na odrzucenie przez ortodoksyjnych chrześcijan koncepcji preegzystencji dusz i będącej jej konsekwencją metempsychozy. Jedynie Orygenes próbował pogodzić preegzystencję duszy z chrześcijańską wizją człowieka. W swoim głównym dziele $O$ zasadach twierdzi, że Bóg - Stwórca (Logos) stworzył z niczego odwiecznie duchy (nous), które były pierwszymi i doskonałymi stworzeniami. Duchy te obdarzone są wolnością i zdolnością do działania, tzn. poznawania. Te z nich, które wybrały kontemplację Boga, zachowały doskonałość swej natury i stały się aniołami, różniącymi się między sobą jedynie mniejszą lub większą bliskością Boga; te zaś, które swe poznanie zwróciły 
ku sobie, zgrzeszyły i upadły. Głębia tego upadku także uzależniona była od tego, jak bardzo duchy odwróciły się od Boga. Aby powstrzymać upadek tych, których grzech nie był nieskończony, Bóg stworzył materię, która jako kres stworzenia zatrzymała upadek duchów w ciałach, dla których stały się duszami ludzkimi. Upadek duchów jest dla Orygenesa tożsamy z grzechem pierworodnym (por. Orygenes 1996, s. 131). Jest on jednocześnie przyczyną zła. Orygenes, inaczej niż Plotyn i inni neoplatonicy pogańscy, nie ujmuje go jedynie jako wypływającego z konieczności natury braku (deprivatio), lecz jako płynący z woli występek (depravatio) (Chadwick 1967, s. 188). Świat cielesny, stworzony przez Boga, jest dobry, ponieważ nie tylko powstrzymuje upadek duchów, ale też umożliwia poprawę, stając się punktem wyjścia dla odrodzenia dusz przez wznoszenie się ku Bogu, czego wzorem i warunkiem jest wcielenie Boga i odkupienie dokonane przez Chrystusa. Dzieło odkupienia ma charakter uniwersalny: nie zostanie zakończone, dopóki wszystkie dusze ludzkie i demony nie zostaną ponownie pozyskane przez boskie miłosierdzie i zwrócą się ku swemu Stwórcy rozpoznawszy oraz pokochawszy Go jako najwyższe dobro. Apokatastaza (powszechny powrót stworzenia do Stwórcy) w ujęciu Orygenesa nie znosi, ale podkreśla wolność jednostek, jednocześnie akcentując wszechmoc Boga, wpierającego dusze w przezwyciężeniu nawet największego grzechu (por. Altaner, Stuiber 1990 s. 296-297).

Orygenesowa koncepcja stworzenia człowieka, zakładająca preegzystencję duszy, nie zyskała uznania autorytetów kościelnych. Nie oznaczało to jednak także, że odrzucona została nauka widząca w ciele coś zewnętrznego i przygodnego względem człowieka, utożsamionego odtąd z duszą (por. Altaner, Stuiber 1990, s. 292-293). Wybierając platonizm, chrześcijaństwo zdecydowało się porzucić afirmację cielesności właściwą dla judaizmu, z którego się wywodziło. Ciało stało się dla duszy narzędziem, ważnym o tyle, o ile mogło być narzędziem służącym jego poprawie bądź zgubie, ale nieinteresującym jako coś samo w sobie ${ }^{3}$. Także zaproponowana przez Orygenesa uniwersalistyczna koncepcja apokatastazy napotykała, przynajmniej w niektórych interpretacjach, krytykę władz kościelnych. Dzięki ojcom kapadockim wszakże, a szczególnie Grzegorzowi z Nyssy, znalazła swoje miejsce $\mathrm{w}$ tradycji teologicznej Wschodu (por. Altaner, Stuiber 1990, s. 416), a dzięki Janowi Szkotowi Eriugenie (który korzystał z pism Nysseńczyka) pozostawiła znaczący ślad także w tradycji Zachodu (Jan Szkot Eriugena 2009, s. 61).

Drugi z wybranych przeze mnie autorów, Dionizy Pseudo-Areopagita, jest przykładem autora całkowicie tożsamego ze swym dziełem, nie

${ }^{3}$ Wyraźnie widać to u św. Augustyna, por. (św. Augustyn 1998, ks. XIV: 24, s. 502-505). 
wiemy bowiem o nim nic ponad to, co ujawniają teksty jego autorstwa, i nawet data ich powstania jest jedynie przybliżona (przełom V i VI w.). Fałszywa ich atrybucja Dionizemu Areopagicie, pierwszemu biskupowi Aten, niewątpliwie pomogła im zyskać rozgłos, ale sława ta była całkowicie zasłużona. Szczególnie cztery dzieła: Teologia mistyczna, O imionach Bożych oraz O hierarchii kościelnej i O hierarchii niebiańskiej oddziałały na wyobraźnię religijną i teologiczną zarówno na Wschodzie, jak i Zachodzie (znane tam były od drugiej połowy VIII w., a popularne od połowy następnego stulecia, kiedy przetłumaczył je Jan Szkot Eriugena $)^{4}$.

Pseudo-Dionizy zwraca uwagę, że podstawowym problemem teologii jest to, iż musi ona mówić o Bogu językiem człowieka, gdyż nawet w tekście objawionym, w Biblii, język jest zapożyczony z opisu stworzeń. Boga zatem możemy przedstawiać zgodnie z naszym, a nie Jego, stopniem doskonałości. Oczywiście, Bóg sam w sobie jest doskonale poznawalny, ale jedynie dla siebie. Dla nas w sobie jest całkowicie niepoznawalny, co nie znaczy, że zupełnie nic nie możemy o nim powiedzieć. Wiedza o Bogu jest nam dostępna w sposób pośredni dzięki temu, co nam o sobie ujawnił (por. Pseudo-Dionizy Areopagita 1997, s. 48-49).

Poglądy teologiczne Pseudo-Dionizego ukształtowały się na podstawie wcześniejszej tradycji myśli neoplatońskiej: zarówno chrześcijańskiej, wywodzącej się ze źródeł kapadockich i aleksandryjskich, jak i pogańskiej, przede wszystkim od Proklosa, który był dziedzicem obu głównych szkół, tak ateńskiej, jak i aleksandryjskiej (por. Stępień 1999, s. 16-18). Jest rzeczą godną uwagi, że wpływ zwalczającego chrześcijaństwo Proklosa jest najbardziej widoczny w O hierarchii kościelnej. Dzieło to jest bowiem wykładem chrześcijańskiej teurgii, dyscypliny dotyczącej praktyki relacji z Bogiem (bądź bogami). U Proklosa odwoływała się ona do magii naturalnej i koncepcji sympatii, u pseudo-Dionizego natomiast główną rolę w praktykach teurgicznych odgrywały chrześcijańskie sakramenty i rytuały obdarzone dzięki łasce boskiej nadnaturalnymi właściwościami. To one, bardziej niż dobre uczynki, są narzędziami, dzięki którym dusza może wspomagać się w drodze poznania Boga (por. Sheldon-Williams 1967, s. 458-459).

Teurgia sakramentalna jest tylko jednym z etapów drogi do Boga, której kresem jest mistyczne zjednoczenie. Cały schemat tej drogi, opisany w jego głównych dziełach, ma charakter trójdzielny. Bezpośrednią inspiracją tego podziału jest, rzecz jasna, Trójca Święta, ale źródła ujmowania troistości jako głębokiej charakterystyki złożonej rzeczywistości sięgają głębiej, do pogańskiego neoplatonizmu Plotyna i jego kontynuatorów:

${ }^{4}$ Na temat roli Eriugeny jako tłumacza Pseudo-Dionizego i ojców kapadockich, por. (Kijewska 2009, s. 24-28). 
Porfiriusza, Jamblicha i Proklosa. To oni odnajdują troistość w różnych aspektach, w jakich ukazany może być byt, dzieląc je na to, czym coś jest samo przez się i samo w sobie, na to, czym jest jako przyczyna sprawcza, od której pochodzą i w której partycypują inne byty, i wreszcie na to, czym jest jako przyczyna celowa, do której, dzięki partycypacji, powracają jej skutki (por. Sheldon-Williams 1967, s. 458-459). Stosownie do tego Pseudo-Dionizy porządkuje swoje dzieło, wyróżniając trzy aspekty (postacie) teologii: katafatyczna, symboliczną i mistyczną (apofatyczną) (por. Pseudo-Dionizy Areopagita 1997, s. 167-168).

Katafatyczna teologia ujmuje Boga jako przyczynę sprawczą form, rozpatrywanych jako atrybuty orzekane o Bogu. To są właśnie Boskie Imiona będące przedmiotem traktatu o tej samej nazwie. Pseudo-Dionizy zwraca uwagę na to, że kontemplacja Bożych imion pozwala nam widzieć Go zarówno jako jedynego Boga, jak i Trójcę. Na to pierwsze rozumienie wskazują imiona jednoczące, odnoszące się bez żadnej różnicy do Boga we wszystkich jego przejawach (teofaniach), takie jak Dobro, Światło, Piękno, Prawda czy Miłość, zbierane przez niego w trójki, z których najwyższą tworzą Mądrość, Życie i Byt: Mądrość (sophia) jako przedwieczne mieszkanie form wszelkich możliwych bytów i niebytów, Życie jako moc (dynamis) nadająca istnienie wszystkim rzeczom i Byt jako pokój (eirene) doprowadzający kon308 flikty do harmonii i wielość do jedności (por. Armstrong 1967, s. 461-462). Drugi zestaw imion pozwala na uchylenie rąbka tajemnicy Trójcy Świętej, jej bowiem dotyczą imiona różnicujące, znane nam jedynie dzięki objawieniu: Ojciec, Syn i Duch Święty. Sam podział także wskazuje na symboliczne znaczenie trójki: imiona ujmowane są 1) wspólnie, 2) jako różnicujące, 3) jako jednoczące. Pseudo-Dionizy podkreśla jednak, że wszystkie bez wyjątku imiona, jakie przypisujemy Bogu, nawet Trójca i Jedność, są usiłowaniami nazwania tego, co nie ma nazwy, jest bowiem nadsubstancjalne, przekraczające wszystko i jako takie imiona te mają nas w kontemplacji wznosić na poziom aniołów. Kontemplacja imion ma zatem być swego rodzaju chrześcijańską mantrą pozwalającą wyjść poza ograniczenia naszej natury (por. Pseudo-Dionizy Areopagita 1997, s. 58-71).

Ujmująca Boga jako przyczynę celową teologia symboliczna omawiana jest przez Pseudo-Dionizego w Hierarchii kościelnej i Hierarchii niebiańskiej. Bóg widziany jest w nich jako ten, do którego dusza wznosi się poprzez symbole zmysłowe i inteligibilne. Wiedza zdobyta na drodze katafatycznej wnosi do hierarchii wszystko to, co może zostać poznane tak, by mogło zostać ujęte jako wyraz boskiej opatrzności i boskiego chcenia przenikających świat zmysłowy i inteligibilny. Przejawami tego boskiego działania są logoi (słowa, pojęcia), które umożliwiają wznoszenie się od tego, co poznawalne, do tego, co niepoznawalne, by ostatecznie doprowadzić do zjednoczenia $\mathrm{z}$ przekraczającą wszelkie rozumienie 
transcendentną Jednią. W tej drodze punktem wyjścia jest świat zmysłowy, ujawniający się nam w poznaniu zmysłowym. Jednak ponieważ dzięki uczestnictwu w Bogu-Stwórcy jest on wypełniony logoi, staje się dla nas światem symboli, które choć zanurzone w materii, pozwalają dzięki analizie teologicznej odrzucić tę materialność i skupić się na istotnej, tzn. nadprzyrodzonej treści symboli. Przejście do niej jest jednocześnie pierwszym etapem teologii apofatycznej, wymaga bowiem zanegowania tego, co materialne, zachowując znaczenie symbolu. Pełne ujęcie apofatyczne będzie wymagało także zanegowania samego znaczenia (por. Sheldon-Williams 1967, s. 463-464).

Boskie logoi nadają światu triadyczną strukturę, która przejawia się na wszystkich trzech poziomach hierarchii: prawnej, kościelnej i niebiańskiej, odpowiadających światom rzeczy, ludzi i aniołów, z których każda naśladuje Boga $\mathrm{w}$ takiej mierze, $\mathrm{w}$ jakiej jest to dla niej możliwe. $\mathrm{W}$ ten sposób hierarchie te stają się także teofaniami. Jednocześnie są one symbolami wznoszenia się duszy do Boga. Przejście od hierarchii prawnej do kościelnej jest oczyszczeniem symbolu z jego materialności, natomiast przejście od kościelnej do niebiańskiej jest oświeceniem, iluminacją pozwalającą na uczynienie wielości symboli na tyle przejrzystymi, by ujrzeć w nich obraz Jednego. Ta droga wyznacza kierunek ku teologii apofatycznej (mistycznej), w której dusza doprowadzona zostanie do niewysławialnego zjednoczenia z Bogiem $\mathrm{w}$ akcie przebóstwienia (theosis), osiągając w ten sposób ostateczną doskonałość (por. Sheldon-Williams 1967, s. 465) 5 . Symbole występujące na tych etapach wznoszenia się duszy różnią się stopniem oddalenia od boskiego Prototypu i także układają się w triady: np. oczyszczenie przez Pismo Święte, oświecenie przez chrzest i zjednoczenie przez eucharystię (por. Pseudo-Dionizy Areopagita 1999, s. 121137). Bardziej od symboliki sakramentów znana jest pseudo-dionizyjska symbolika niebiańska trzykroć troistych chórów anielskich, później usystematyzowana (m.in. przez Hildegardę z Bingen i św. Tomasza z Akwinu) i powszechnie wykorzystywana w chrześcijańskiej ikonografii (por. Pseudo-Dionizy Areopagita 1999, s. 71-84; s. 103-110). Ich przedstawienia mają dla Pseudo-Dionizego głęboki sens symboliczny - obrazują bowiem przekazywanie boskiej mądrości, mocy i dobra i umożliwiają wtajemniczonemu coraz pełniejsze uczestnictwo $\mathrm{w}$ anielskich działaniach, wynosząc go stopniowo do progu przebóstwienia, gdzie negatywna dialektyka apofatycznej teologii ostatecznie uzdatnia duszę do przejścia od tego, co było tylko odbiciem Boga, hierarchii niebiańskiej, do zjednoczenia z Nim samym (Stępień 1999, s. 20-23).

${ }^{5}$ O akcie theosis por. List II. Do tego samego Gajusza, mnicha w: (Pseudo-Dionizy Areopagita 1997, s. 173-174). 
Ostatni etap drogi, teologia mistyczna, wyrasta $z$ dwóch poprzednich. Zgodnie z tradycją wywodzącą się od Grzegorza z Nazjanzu, jednego z ojców kapadockich, Pseudo-Dionizy podkreśla, że oświecenie musi zakładać oczyszczenie, inaczej grozi mu przekształcenie się $\mathrm{w}$ idolatrię (por. Sheldon-Williams 1967, s. 467) (to samo ostrzeżenie znajdziemy cztery wieki później u Bernarda z Clairvaux skierowane, w zawoalowany sposób, do Piotra Abelarda [por. Bernard z Clairvaux 2000, s. 99-104]). Oczyszczenie powstrzymuje duszę nie tylko od czczenia idoli na poziomie symboli zmysłowych, ale także powstrzymuje ją od czczenia idoli umysłowych, takich jak samo piękno czy sama prawda na poziomie symboli inteligibilnych, choć jest to trudniejsze, jako że dla człowieka są nie do odróżnienia od logoi, które się pod nimi skrywają. $Z$ tego powodu, powie Pseudo-Dionizy, należy raczej zaufać niepodobnym symbolom niż podobnym. Ta zasada teologii symbolicznej doprowadza nas do logicznej konkluzji, należącej już do teologii apofatycznej, że przyczyna bytu jest nie-Bytem (por. Pseudo-Dionizy Areopagita 1997, s. 169).

Teologię mistyczną uprawiać można jedynie na sposób apofatyczny, całkowicie wychodzi ona bowiem poza możliwość ujęcia w pojęciach; nic $\mathrm{w}$ niej nie może być wytłumaczone czy objaśnione, a jedynie przeżyte. $Z$ tego też powodu pozostaje w całkowitym ukryciu. Ona także jest 310 triada, ale triadą wtajemniczenia: jej oczyszczenie to odrzucenie pojęć intelektualnych, jej oświecenie to szczególna transcendentna gnoza, która ujawnia, że Bóg jest niepoznawalny, i dlatego jest ona naprawdę agnozja; jej zjednoczenie jest wreszcie zjednoczeniem $\mathrm{z}$ niepoznawalnym (por. Pseudo-Dionizy Areopagita 1997, s. 170). Pierwszą fazą drogi apofatycznej jest odrzucenie Imion Bożych afirmowanych w teologii katafatycznej. Pseudo-Dionizy pokazuje, dlaczego jest to konieczne: gdybyśmy ich nie odrzucili, takie imiona jak „,król” czy „pan” prowadziłyby nas do antropomorficznego wyobrażenia Boga. Sekwencja tych negacji doprowadza nas ostatecznie do zaprzeczenia, że Bóg jest, po to by stwierdzić, iż jako transcendentna przyczyna istnienia i nieistnienia jest inaczej niż wszystko. Bóg jest dla niego nad-bytem (hyperousios), który nie jest ani bytem, ani niebytem, ale jest transcendentny wobec obydwu. Choć jest realny, to żywość jego realności oślepia poznające umysły do tego stopnia, że nie może się stać przedmiotem wiedzy nawet jako Jedno. Przeciwnie - możemy go ująć jako nieskończoną wielość obiektów opatrzonych przedrostkiem „,nad-", takich jak nad-byt, nad-mądrość, nad-dobro itp., które jednocześnie mogą i nie mogą być przedmiotem kontemplacji jako jej ukryte obiekty. Ta agnostyczna kontemplacja jest drugą fazą mistycznej teologii (por. Sheldon-Williams 1967, s. 468-470).

W odróżnieniu od Grzegorza z Nyssy Pseudo-Dionizy stwierdza, że poznanie niepoznawalności Boga nie jest tylko emocjonalnym 
doświadczeniem niewyczerpywalnej radości, ale i świadomością obecności pewnej realności, niewysławialnej, ale rzeczywistej. To umożliwia mu przejście do ostatniej fazy teologii mistycznej: od niewiedzy (agnosia) do zjednoczenia (henosis). Agnozja nie oznacza jakiejś porażki intelektu, lecz przeciwnie - jego całkowite rozpłynięcie się w Bogu. Wyklucza ona to, co zmysłowe, i dlatego nie może być w żaden sposób przekazana; wyklucza także to, co inteligibilne, i dlatego nie można się jej nauczyć. Jest wizją jednocząca, niewysławialną i ekstazą miłości. Ekstaza nie oznacza jednak dla Pseudo-Dionizego odrzucenia woli i intelektu, ale takie rozszerzenie ich możliwości poza to, co im przyrodzone, że nie polegają one już na sobie, ale na boskiej Opatrzności, która wychodzi im naprzeciw w taki sposób, że odwiecznie zstępuje w dół, przenikając wszelkie hierarchie aż do samego ich najniższego kresu, i unosi, roztapiając w sobie te dusze, które osiągnęły najwyższy stopień miłości, nie pozwalając, by ci, którzy ukochali, pozostawali sami ze swoją miłością. Oznacza to, że ekstazy są dwie, bo i Bóg, i dusza wychodzą poza własną naturę: On, zstępując ku niej przez liczne teofanie i niezliczone symbole; ona, wstępując ku Niemu opisaną wyżej drogą. Nie oznacza to jednak, że dla Pseudo-Dionizego Bóg "ś́ciągany" jest w dół jak w teurgii Proklosa, ale transcendencja Boga działa poprzez wszelkie hierarchie jako jedyna przyczyna sprawcza i celowa będąca źródłem powrotu dla wszelkich bytów, poczynając od świata zmysłowego, przez ludzi, po anioły. Hierarchie te muszą zostać odrzucone jak niepotrzebna drabina, zanim dusza wyjdzie poza siebie i wejdzie w boską ciemność ekstazy. Jako porządek są symbolem stabilności etapów wiodących do Boga: oczyszczenia, oświecenia i doskonałości. Jako wiedza są iluminacja która musi poprzedzać wizję uszczęśliwiającą. Jako działanie są kontemplacją tak intymna, że staje się ona tym, co kontempluje. Ostatecznie dusza musi wyjść poza wszelki porządek, wiedzę i działanie, poza samą niebiańską hierarchię, która jest najwyższym przedmiotem kontemplacji, po to, by dzięki agnozji znaleźć się w objęciach Boga i stać się z Nim doskonałą jednością (por. Sheldon-Williams 1967, s. 472).

Omówionym przeze mnie przykładom poglądów neoplatońskich myślicieli chrześcijańskich można zarzucić jednostronność, zostały one bowiem wybrane celowo po to, by udowodnić zadeklarowaną na wstępie tezę o bliźniaczym charakterze metaforycznych Aten i Jerozolimy, choć można by także znaleźć przykłady przeciwne, i to nie tylko u Tertuliana. Taki mój zamysł nie miał na celu unieważnienia wielości stanowisk chrześcijan i platoników w tym decydującym dla kształtu naszej kultury okresie (III-VI w.); chodziło mi zwrócenie uwagi na to, że nawet deklarowana wrogość wobec przedstawicieli „drugiej strony” nie była w stanie zgasić intelektualnej ciekawości. Sądzę, że wybrane przeze mnie przykłady wystarczająco dobrze pokazały, że stereotypy przeciwstawiające sobie ścisłe, 
racjonalne, filozoficzne Ateny i rozwichrzona, szukającą cudów i proroctw religijną Jerozolimę sa, jak to zazwyczaj bywa, daleko idącym uproszczeniem, a w interesującym nas okresie po prostu nadużyciem. To ateński filozof Proklos próbujący ratować pogaństwo ${ }^{6}$ jest dla Pseudo-Dionizego nauczycielem szukania mistycznej symboliki w rzeczywistości po to, by osiągnąć kontakt z bóstwem. To neoplatońska filozofia akcentująca znaczenie Triady, a nie Biblia, jest dla Orygenesa i Pseudo-Dionizego inspiracją do refleksji nad trynitarną naturą Boga. To chrześcijanin Orygenes jest tym, który zmusza pogańskich filozofów, by podjęli próbę racjonalnej interpretacji swojej wiary. To chrześcijanin Pseudo-Dionizy wprowadza racjonalny porządek do mitologicznego bestiarium, układając je w hierarchie symbolicznie obrazujące drogę duszy do mistycznego zjednoczenia z Bogiem. W tym wzajemnie się inspirującym splątaniu wątków z czasem dostrzeżono dowód wspólnego, boskiego pochodzenia wiedzy religijnej i filozoficznej, a humanista Agostino Steuco z Gubbio nadał mu w swym eponimicznym dziele z 1540 r. nazwę philosophia perennis (odwieczna filozofia), w ten sposób u schyłku epoki przednowożytnej dopełniając jej wielką syntezę (por. Augustinus Steuchus 1540). Jest rzeczą godną uwagi, że myśl Platona, duchowego ojca Zachodu ${ }^{7}$, rozwinęła się tak znacząco dzięki mieszkańcom terenów nazwanych później Lewantem: Egiptu, Palestyny, Syrii i Azji Mniejszej. Pokazuje to dobitnie, że Wschód i Zachód są razem równymi i ważnymi źródłami duchowej inspiracji, a próby ich rozdzielenia czy zanegowania znaczenia któregokolwiek z nich są z góry skazane na niepowodzenie.

\section{Bibliografia}

Altaner B., Stuiber A. (1990), Patrologia, PAX, Warszawa.

Armstrong A.H. (red.) (1967), The Cambridge History of Later Greek and Early Medieval Philosophy, CUP, Cambridge.

Augustyn Aureliusz, św. (1998), Państwo Boże, Antyk, Kęty.

Bernard z Clairvaux, św. (2000), O miłowaniu Boga, Klub Książki Katolickiej, Poznań.

Chadwick H. (1967), Philo and the Beginnings of Christian Thought, [w:] A.H. Armstrong (red.), The Cambridge History of Later Greek and Early Medieval Philosophy, CUP, Cambridge.

Gilson E. (1987), Historia filozofii chrześcijańskiej w wiekach średnich, PAX, Warszawa.

${ }^{6}$ Marinus z Samarii w swej biografii Proklosa pisze, że po usunięciu posągu Ateny z Partenonu bogini przyszła do niego we śnie, prosząc o schronienie, por. (Marinus of Samaria 1986, s. 53-54).

7 Taki stosunek do Platona wyraża najlepiej słynna maksyma Alfreda Northa Whiteheada: „The safest general characterization of the European philosophical tradition is that it consists of a series of footnotes to Plato" (Whitehead 1979, s. 39). 
Jan Szkot Eriugena (2009), Periphyseon, , Wydawnictwo Marek Derewiecki, Kęty.

Kijewska A. (2009), Wstęp, [w:] Jan Szkot Eriugena, Periphyseon, Wydawnictwo Marek Derewiecki, Kęty.

Klemens z Aleksandrii (1994), Kobierce, Pax, Warszawa.

Marinus of Samaria (1986), The Life of Proclus or Concerning Happiness, Phanes Press, Grand Rapids.

Orygenes (2001), Contra Celsum libri VIII, Brill, Leiden-Boston.

Orygenes (1996), O zasadach, WAM, Kraków.

Pietras H. (1996), Wprowadzenie, [w:] Orygenes, O zasadach, WAM, Kraków.

Pismo Święte Starego i Nowego Testamentu (2000), Pallotinum, Warszawa, Poznań.

Plotyn (2000), Enneady I-III, Akme, Warszawa.

Pseudo-Dionizy Areopagita (1997), Pisma teologiczne, t. 1, Znak, Kraków.

Pseudo-Dionizy Areopagita (1999), Pisma teologiczne, t. 2, Znak, Kraków.

Roberts A., Donaldson J. (red.) (1994), The Ante-Nicene Fathers, t. 3, Hendrickson Publishers, Peabody.

Sheldon-Williams I.P., The Greek Christian Platonist Tradition from the Cappadocians to Maximus and Eriugena, [w:] A.H. Armstrong (red.) (1967), The Cambridge History of Later Greek and Early Medieval Philosophy, CUP, Cambridge.

Steuchus Augustinus (1540), De perenni philosophia, Seb. Gryphius, Lugduni.

Stępień T. (1999), Przedmowa, [w:] Pseudo-Dionizy Areopagita, Pisma teologiczne, t. 2, Znak, Kraków.

Whitehead A.N. (1979), Processes and Reality, The Free Press, New York.

Streszczenie: Chrześcijański neoplatonizm - synteza duchowych tradycji Wschodu i Zachodu

Związki chrześcijaństwa z neoplatonizmem datują się niemal od samego początku tej religii. Choć wywodziła się z judaizmu, szybko zyskała wyznawców wśród Greków i zhellenizowanych mieszkańców wschodnich prowincji cesarstwa rzymskiego, z których wielu miało wykształcenie filozoficzne. Odrodzony w Aleksandrii platonizm stał się dla chrześcijan narzędziem do poznawania własnej wiary i objaśniania jej innym, a $\mathrm{w}$ konsekwencji jego niezbywalnym elementem na równi $\mathrm{z}$ tradycją biblijną. Poglądy dwóch wybitnych myślicieli okresu patrystycznego: Orygenesa i Pseudo-Dionizego Areopagity, wywodzących się rzymskiego Wschodu, są przykładem na to, jak myśl neoplatońska tworzy ramy dla religii Jezusa i jego uczniów.

Słowa kluczowe: wczesne chrześcijaństwo, neoplatonizm, patrystyka

Summary: Christian Neoplatonism - the Synthesis of Spiritual Traditions of the East and the West

Close relations between Christianity and Neoplatonism date back to the very early days of the religion. Although it had its origin in Judaism, it soon found followers among Greeks and Hellenized inhabitants of eastern provinces of the Roman Empire, many of whom had philosophical 
education. Platonism, reborn in Alexandria, became for Christians a tool useful both for interpreting their own faith and for explaining it to gentiles and soon was seen as an inalienable part of the Christian doctrine on a par with the biblical tradition. The teachings of two eminent thinkers of the Patristic period, Origen and pseudo-Dionysius the Areopagite, both hailing from the Roman East, are examples how Platonic doctrine forms a framework for the religion of Jesus and his disciples.

Keywords: early Christianity, Neoplatonism, Patristic literature 